\title{
THE 'ERASMUS GENERATION' AND TURKEY: THE EFFECT OF THE ERASMUS PROGRAMME ON PERCEPTIONS ABOUT TURKEY AND ITS EU MEMBERSHIP BID
}

\author{
Selcen Oner \\ Bahcesehir University, Turkey
}

\begin{abstract}
The main research question of this study is how participation to Erasmus programme influences European students' perceptions of Turkey and its EU membership bid. The study evaluates the Erasmus programme's influence on student identities, particularly their European identity, and their perceptions about the compatibility of European and Turkish identity by analysing the responses of incoming Erasmus students at Bahçeşehir University (İstanbul) in Turkey to open-ended questionnaire surveys conducted at the beginning and end of the semesters between 2009 and 2011 to investigate the extent that the Erasmus programme can influence the perceptions of these students about Turkey. In addition, semi-structured in-depth interviews, conducted by the author with incoming Erasmus students at Bahçeşehir University at the end of the semesters between 2012 and 2014, were analysed qualitatively to evaluate the Erasmus programme's influence on the perceptions of these students about Turkey, Turkey's EU membership bid, their perceptions of the compatibility of European identity and Turkish identity and the role of the Erasmus experience in constructing a European identity in the young generation.
\end{abstract}

Keywords: Turkey; European Union; Erasmus; European Identity and Prejudice. 


\section{Introduction}

Introduced in 1987, the Erasmus (European Action Scheme for the Mobility of University Students) programme is one of the most visible practices of the EU influencing directly the lives of EU citizens, and usually considered one of the best components of EU policy. It is also one of the main instruments for constructing European identity.

Although education policy still remains mainly under the sovereignty of member states, the EU has tried to increase cooperation and coordination between them regarding higher education through the Bologna process. This has expanded to 47 countries, covering three million students. Russia and Turkey also participate in the Bologna process alongside EU member states (Aba 2013, 101). Through the Erasmus programme, it has encouraged interactions between students, professors and university officials. The EU's educational policy has tried to incorporate a European dimension into national and regional education systems (Brock and Tulasiewicz 1999).

Erasmus formed part of the EU's Lifelong Learning Programme, which had a budget of 3.1 billion Euros for 2007-2013. In 1987, 3,244 students from 11 countries participated in the programme, while by 2012-2013 these figures had risen to approximately 270,000 students from 33 countries. These included Iceland, Liechtenstein, Norway, Switzerland and Turkey, in addition to EU member states. Since it began in 1987-88, Erasmus, which is the largest such programme in the world, has provided over three million European students with the opportunity to go abroad and study at a higher education institution, while promoting the internationalisation of the European higher education system and contributed to its modernisation (Erasmus 2014, 5-6). It has also encouraged student, academic faculty and staff exchanges between Europe's universities (Papatsiba 2006, 99; cited in Mitchell 2012, 491). Spain sent the highest number of students abroad with 39,249 students, followed by France, Germany, Italy and Poland. The most popular destination for Erasmus students was Spain, which received 40,202 students, followed by Germany, France, the UK and Italy (Erasmus 2014, 7).

The motto of Erasmus programme is 'bringing students to Europe, bringing Europe to all students'. The idea is that bringing together students of different nationalities may enhance a sense of European identity among its participants and thereby creating European citizens (Prodi 2002; Figel 2006; Figel 2007; cited in Mitchell 2012, 491). Thus, the Erasmus programme has been promoted by the Commission as a means to increase 'European consciousness' among its 
participants. It also helps European students to prepare themselves to work in an increasingly transnational economy (Mitchell 2012, 491). Youth exchanges in the EU have contributed to the goal of establishing 'ever-closer union of the peoples of Europe' which is the goal of the Rome Treaty. The Erasmus programme is one of the EU's main instruments for educational exchanges among the younger generations, including cultural exchanges, leading to the emergence of an 'Erasmus generation'. The programme was revised for 2014-2020 and renamed 'Erasmus +', incorporating the fields of education, training, youth and sport. One of the Bologna goals for 2020 is that at least $20 \%$ of all graduates from the European Higher Education Area should have spent a period of time studying or training abroad (Erasmus 2014, 6).

Erasmus students' experiences include learning about different cultures, meeting new people and being more independent, which influence their selfconfidence and career plans, improves their academic knowledge, increases their opportunities to learn new foreign languages and improves their foreign language skills (Kropnik and Krzaklewska, 2006; cited in Mutlu et al. 2010). Student mobility is also thought to contribute to intercultural dialogue (Aba 2013, 107), while their perceptions about life, their social and political views can change more easily than those of older people by living in different societies and cultures. In this way, it hoped that the prejudices of younger people can be eliminated more easily than is possible with older generations.

Stereotypes are perceptions held about groups or individuals based on previously formed opinions (Samovar and Porter 1991; cited in Keles 2013, 1516), usually small pieces of information that help people to understand the world by categorizing people and situations that they encounter (Barna 1997; cited in Keles 2013, 1516). However, applied to individuals or different communities, stereotypes are often problematic because they are usually overgeneralized, simplistic or exaggerated. Stereotypes can also cause people to assume that a widely held belief is true, although it is not (Keles 2013, 1516). Personal inter-cultural contacts help people to overcome such prejudices and stereotypes about each other and bring them closer together (Sigalas 2009, 5). Since Erasmus students of different nationalities spend time together at the university, in dormitories, at Erasmus parties and while travelling together, they learn how to adapt to different cultures. Moreover, these social settings provide an appropriate context for eradicating prejudices and stereotypes (Mutlu et al. 2010, 39-42).

Several previous empirical studies indicate that Erasmus participants tend to identify themselves as European (King and Ruiz-Gelices 2003; Van Mol 2011). The potential of the influence of European mobility for promoting European identity 
has been emphasized by transactionalists such as Karl Deutsch. ${ }^{1}$ Deutsch et al. (1968), for example, argue that increased cross-border people mobility has a crucial influence on international integration and the emergence of a 'we-feeling' among peoples from different cultures. As they note, this is 'probably the most efficient and permanent method of gaining knowledge about human actions and values' (Deutsch et al. 1968, 170; cited in Sigalas 2009, 5). However, Connor (1972) criticised Deutsch for over-optimistically predicting that increased mobility and communication might lead to such a 'we-feeling' (cited in Sigalas 2009, 6). Currently, there is a debate about whether exchange programmes do create a European identity (King and Ruiz-Gelices 2003; Van Mol 2011), or whether those students who already feel European are more likely to participate in the Erasmus programme (Van Mol 2011; Wilson 2011).

Although Turkey has been associated with the EU since 1963 and was granted official candidate status at the Helsinki Summit of December 1999, it is the least wanted candidate country. This is one of the main challenges regarding Turkey's integration with the EU; that member state public opinion is highly sceptical of Turkey's membership bid. Regarding European views, several historic prejudices and stereotypes about Turkey have negatively influenced EU citizens' perceptions about Turkey's membership bid, and this has been joined by rising Islamophobia in Europe, especially after September 11. Moreover, the integration problems of Turkish immigrants in several EU member states have increased prejudices about the cultural compatibility Turkish people and EU member states. Fortunately, increasing opportunities for exchange and participation in common projects can help overcome such prejudices and stereotypes. Turkey's drawn-out accession process has increased Euroscepticism in Turkish public opinion, especially following the stagnation of the negotiation process due to political factors, particularly the Cyprus issue and France's blocking of the process whose former President Sarkozy is against full membership of Turkey.

Turkey became 31st participating country in the Erasmus programme since 2004, since when it has been one of the most active participants, being involved in the SOCRATES, YOUTH and Leonardo de Vinci programmes. The Lifelong Learning Programme started in 2007, and includes COMENIUS for high schools, ERASMUS for higher education, LEONARDO DE VINCI for vocational education and training, and GRUNDTVIG for adult education. 129 Turkish higher education institutions hold the Erasmus University Charter, which enables them to take part in the programme. Between 2004 and 2010, Turkish Higher Education Institutions have

${ }^{1}$ For further detail, see K. Deutsch et al. (1968), Political Community and the North Atlantic Area, Princeton, NJ: Princeton University Press. 
sent approximately 30,000 students abroad and received 9,000 students, while also sending 6,500 teaching staff abroad and hosting 4,300 (Studying in Turkey 2010).

The main research question of this study is how participation to Erasmus programme influences the perceptions of students about Turkey and its membership bid. It evaluates the Erasmus programme's influence on student identities, particularly their European identity, and their perceptions about the compatibility of European identity and Turkish identity. While there have been several previous studies of the role of the Erasmus programme in different participating countries, the literature concerning the influence of the Erasmus programme on incoming Erasmus students to Turkey, and particularly its influence on perceptions about Turkey, is very limited.

This article first explains how the EU's Erasmus programme developed and Turkey's participation in it. Secondly, in order to evaluate Erasmus programme's influence on the perceptions of incoming students about Turkey, it analyses responses to open-ended questionnaire surveys, conducted between 2009 and 2011 which were carried out at the beginning and end of the semesters with Erasmus students at Bahçeşehir University (İstanbul). The extent that the Erasmus programme was able to influence these students' perceptions about Turkey is analysed. The article then considers student responses from 14 semi-structured, in-depth interviews, conducted by the author between 2013 and 2014 with a random selection of incoming Erasmus students to Bahçeşehir University from the department of political science and international relations. A qualitative analysis was carried out to evaluate the programme's influence on the perceptions of these students about Turkey's EU membership bid, the compatibility of European and Turkish identity, and the role of the Erasmus experience in constructing a European identity in the younger generations.

A limitation of this study is that it was conducted in only one university in Istanbul, which is a foundation university based in the centre of Istanbul. To deepen this study's findings, further work should be extended to a greater variety of universities from Istanbul and other cities of Turkey to investigate more broadly the influence of the Erasmus programme on the perceptions of incoming Erasmus students visiting Turkey. 


\section{Erasmus Programme and Its Influence on the Perceptions of Students about Turkey and their European Identity}

The highest level of student flow is from developing to developed countries because, if they gain international education experience, it is usually easier for them to find a job when they return to their home country. The countries receiving the highest number of students have been the USA and the UK, which are English speaking countries. However, with the rise of the developing world, particularly China and South Korea, there has been a decline in international student numbers in the USA and the UK (Aba 2013, 105).

The Erasmus programme aims to unite European societies by encouraging interactions between citizens of different European countries (Reilly 1993). Erasmus has never been just an education programme, as reflected in its official objectives stated in the Council decision of 1987. One of these is: 'To strengthen the interaction between citizens in different member states with a view to consolidating the concept of a People's Europe' (Council 1987, 21-22). Several scholars ${ }^{2}$ also argue that the Erasmus experience may lead to emergence of a European identity.

According to Deutsch (cited in Sigalas 2010), high level international transactions over a period of time may lead to the formation of an integrated community of states and nations by allowing direct contact between people of different nationalities, which may lead to emergence of a 'we-feeling. Fligstein (2008; cited in Demirkol 2013, 655) argues that with the influence of the interpersonal contact among people, they may start to see themselves more as Europeans and less as having only a national identity. Fligstein $(2009,133)$ argues that people who speak foreign languages and have travelled and lived in other European countries tend to have a stronger European identity than those who have not.

One of the goals of the Erasmus programme is to eradicate prejudices through student and academic faculty mobility, and by increasing interactions between European societies to unite them by increasing a European consciousness among EU citizens (Mutlu et al. 2010, 42). Not knowing the other is an influential factor in the emergence and maintenance of prejudices. Once people start communicating with others coming from different cultures and sharing experiences with them then prejudices can be partially eliminated. Breaking down prejudices leads to the emergence of tolerance and understanding (Mutlu et al. 2010, 39-40). As Sigalas (2006) argues, 'the more people socialise with each other, the more they trust

\footnotetext{
${ }^{2}$ For further detail, see N. Fligstein, The EU, European Identity and the Future of Europe, ,Oxford: Oxford University Press, 2008; I. Petit, 'Mimicking History: The European Commission and Its Education Policy', World Political Science Review, Vol.3, 2007.
} 
each other and the closer they feel'. The Erasmus students do not spend all their time at university and at the lectures; they also visit places in the host country and sometimes neighbouring countries; they have a chance to learn about the culture they are living in and they can improve their foreign language skills. Thus, Maiworm and Teichler (1995) found that the Erasmus experience increases knowledge of the host country's culture substantially, while Mitchell $(2012,497)$ reported that most Erasmus students find it easier to communicate with an 'international group' that includes other Erasmus students than with a 'native group' of host-country students.

In spite of its growth, the Erasmus programme still only has a modest reach. 3,000 students participated in 1987, increasing to 100,000 in 2000-2001 and more than 200,000 in 2009-2010, which is less than the target stated in the Lisbon Strategy of $10 \%$ of students in higher education. One factor is that there are still socioeconomic challenges to student mobility, although a certain amount of funding is provided to help students with additional costs while studying abroad (Vossensteyn et al. 2010; cited in Mitchell 2012, 511). In addition, having weak or no foreign language skills also makes students less likely to study abroad (Mitchell 2012, 511).

In 2007, Erasmus became part of the 'Lifelong Learning Programme', which combines educational with vocational training programmes. In addition to EU member states, the Erasmus programme also includes Norway, Iceland, Liechtenstein and Turkey.

As argued by Mitchell (2012, 499-511), the Erasmus programme has a transformative power over the participating students, who usually become more favourable of, and attached to the EU. Three-quarters stated that their experience of studying abroad made them feel more European. It has been shown that younger, better educated people have a greater tendency to identify as European than older, less educated people. ${ }^{3}$ After studying abroad, most Erasmus students stated that they became more interested in other European countries, other European cultures and in the EU, and felt more European. She also found that Erasmus students speak more foreign languages and speak them better than non-mobile students. Nevertheless, in spite of the growth of the Erasmus programme, only a minority of Europeans can benefit from it so its influence on the construction of a European identity is limited. According to Sigalas (2009), the Erasmus experience has helped British students develop a stronger attachment to Europe, and to realize that they have several things in common with those in continental Europe. 'When Erasmus students return back

\footnotetext{
${ }^{3}$ For further detail, see J. Citrin and J. Sides, 'More Than Nationals: How Identity Choice Matters in the New Europe' in R. Herrman, T. Risse and M. Brewer (eds.), Transnational Identities: Becoming European in the EU, New York: Rowman \& Littlefield, 2004.
} 
to their countries, they become ambassadors of European integration' (Wallström 2007, 4; cited in Oborune 2013, 194).

There is more Euroscepticism in the group of non-mobile students, who have not interacted with people from the European countries, than mobile students. Students who participate in Erasmus mostly have good foreign language skills, previous international exchange experience and a multicultural background. The programme has promoted the idea that 'we Europeans are all alike and foster trust and feel closer to Europeans'. However, the number of participating students is still very small in terms of the number needed to promote European identity. The Erasmus programme does not entail the loss of national identity as participating students usually have both a strong national and European identity (Oborune 2013, 193-194). That is, people may hold both a European identity and a national identity together.

According to the Erasmus Student Network (ESN) Surveys $(2005,2006)$ (cited in Krzaklewska and Krupnik 2008), Erasmus students become more openminded and mobile as a result of staying abroad, and developed wide social networks abroad. They stated that they are better prepared for intercultural dialogue. As Krzaklewska and Krupnik (2008) argue, after their Erasmus experience, this may lead to a more tolerant and open society. However, Sigalas (2009) and Van Mol (2009) argue that students who participate in the Erasmus programme already have a European identity before joining the programme.

As well as experiencing other cultures, Aydin (2012) found that some participants emphasized how, during their Erasmus experience, they had opportunities to introduce their own culture to foreigners too. From research conducted at Adam Mickiewicz University in Poznan, Poland, Mutlu et al. (2010, 39-42) found that changes in prejudices after the Erasmus experience were greater in Turkish students than EU students. They argue that this is because EU students already share more similar cultures to the host country so there is less change in their prejudices. For example, $88 \%$ of Turkish students agreed that, during the Erasmus programme, 'I abandoned my prejudices towards new things and people' but only $49.4 \%$ of EU students did. $76 \%$ of Turkish students agreed that 'I got away from my prejudices' while $45.5 \%$ of EU did. Similarly, the figures agreeing with 'I have learnt to live in different cultures' were $92 \%$ for Turkish students and $76.6 \%$ for EU students. Turkish students usually became more eager to learn foreign languages and make friends from other cultures after their Erasmus experience, although none of them were considering settling in any EU country, stating that they would rather visit EU countries as a tourist or student. These findings were supported by 
Yağc1 et al. (2007), who reported that a majority of students stated that they were more open to new cultures and differences after their Erasmus experience.

Mutlu $(2011,101)$ argues that the Erasmus experience usually contributes to students' personal development, particularly increasing their self-confidence, rather than academic development. Students usually refer to concepts such as discovering different cultures, new places and friendships, rather than concepts related with academic issues, such as courses, professors, university and library. She reports that students describe this process as enjoyable and productive. During their Erasmus experience, they enjoy discovering themselves more, as well as new places and cultures, making new friends and living in the 'European spirit'. Students can also introduce their own culture to their friends in the host country. She concludes that 'the students have left the majority of their prejudices behind through crosscultural dialogue. One of the key goals of the Erasmus programme is to remove prejudices through cross-cultural dialogue and to unite societies through increasing European consciousness. Mutlu (2011) argues that the Erasmus programme has been successful in reaching this goal.

In spite of the limited participation of European students in the Erasmus programme, especially because of the limited budget and lack of foreign language knowledge, it has had a crucial influence in increasing interactions between European societies and contributed to strengthening mutual understanding between different cultures.

\section{Erasmus Programme and Its Influence on the Perceptions of Incoming Erasmus Students: The Case of Turkey}

As a signatory country of the Bologna Declaration in 2001, Turkey has been trying to follow its requirements to integrate into the European higher education area. Through the process, Turkey has made crucial structural changes in its higher education system, although there are still many deficiencies in terms of implementation. The Erasmus programme allows European university students from various countries to study for one or two semesters at Turkish universities, and learn about Turkish society and culture. During their stay many of them have a chance to travel around Turkey, some of them learn Turkish, or at least start learning it.

The Turkish National Agency, which is one of the main organizations responsible for the implementation of the Erasmus programme and the Bologna reforms in Turkey, was established in 2002. Turkey's Erasmus programme was launched in 2003 (Aba 2013, 106). 
Between 2007-2008 and 2010-2011 academic years, outgoing student mobility rates in 8 countries grew by more than $40 \%$, with Turkey among them. Although many Turkish higher education students and academic staff have moved abroad for educational reasons, Turkey has not been a popular destination for foreign students. For example, in 2004, 1,142 Turkish students were sent abroad but only 299 Erasmus students came to study in Turkey. However, these figures rose to 10,095 and 4,288 respectively in 2010-2011 (European Commission 2012; cited in Aba 2013, 105).

Especially following the economic crisis in Europe, Europeans' interest in studying and working in Turkey has risen. The increasing number of foundation universities in Turkey, especially in major cities like Istanbul, Ankara and Izmir, many of which teach in English, has also made Turkey more attractive for Erasmus students.

Prejudice can be defined as unfair or intolerant attitudes towards another person or group because they belong to a specific religion, race or nationality (Samovar and Porter 1991; cited in Keles 2013, 1517). There are many historically formed prejudices and stereotypes about Turkey in European societies. The Erasmus programme provides several opportunities to learn more about the host country and its culture, which may help to eradicate the students' prejudices and stereotypes about that country. Demirkol $(2013,653)$ argues that educational mobility programs have a positive influence on the cultural integration. From studying Erasmus students in Turkey in 2011-2012 he found that they came to see Turkey 'as a part of the EU; they think Turkey's accession to the EU would favour the mutual comprehension of European and Muslim values, and a large majority of the students approve Turkey's accession to the EU' once Turkey complies with the EU's conditions.

The surveys were conducted by the author between 2009-2011 among the incoming Erasmus students at Bahçeşehir University in Istanbul, both at the beginning of the spring and autumn semesters and another survey was conducted at the end of these semesters with those incoming Erasmus students, who come from various departments. 53 Erasmus students were surveyed at the beginning of the two semesters in 2009-2011, originating from various countries, including Germany, Denmark, Latvia, Sweden, Poland, the Netherlands, Belgium, Lithuania, Italy, Austria and Bulgaria. Most of the students who participated in both the surveys and the in-depth interviews were from Germany.

The responses indicated that most students chose Turkey, and particularly Istanbul, in order to discover a new different culture. Most of them had never been to 
Turkey before and did not know so much about Turkey, having usually only gained basic knowledge from the internet. One of the Erasmus students from Lithuania stated: 'I knew very little about culture, food and people.' Some of them knew that, in 2010, Istanbul was a European capital of culture, and most of them were already interested in Turkey before they came. Nearly all had chosen Turkey in order to discover a different culture. Some chose Turkey, and particularly Istanbul, because some of their friends who had visited Turkey had recommended or else had come to Turkey on holiday. Some chose Istanbul, and particularly Bahceșehir University, because the teaching language is English and they wanted to improve their level of English. Some of them stated that they expected to learn Turkish, and about the Turkish education system and Turkish politics. In addition to these, some of them stated that they expected to make new friends, to gain experience of studying abroad, to improve their vision and their knowledge in their fields of study, and to have fun.

When asked what they had known about Turkey before they came, some referred to Turkish history, particularly the Ottoman era. This prior knowledge was mostly based on the mass media or the comments of friends who had visited Turkey before. Citizens of EU countries who are of Turkish origin, especially German Turks, are usually interested in studying in Turkey as an Erasmus student. Some of these students stated that they had wanted to learn Turkish and about Turkish culture because they are living together with Turkish people. They also stated that they already knew something about Turkish culture because of the Turkish community in their country. One of the German students stated that 'there are many Turkish people in Germany but they live separately from parts of society. So it is a good chance to get used to Turkish culture.'

Another 17 students participated in the survey conducted at the end of the semesters in 2009-2011 at Bahçeşehir University. They were drawn from different departments and countries, including the Netherlands and Germany, with some being of Turkish origin, Italy, Spain, France, Bulgaria, Poland, Sweden and Denmark. All participating students were satisfied or very satisfied with their experience. They were mostly very satisfied with their stay in Turkey, particularly in Istanbul. One of the students from Italy defined Istanbul as a 'magic city' while another from Bulgaria stated that ' $I$ fell in love with Istanbul. It is amazing, both a modern and ancient city.' A Danish student stated that 'I am quite certain that I will return to Istanbul again'. Regarding the positive aspects of their stay, they mentioned the people they had met from different countries, learning about a new, different culture, improving their level of English, travelling around during their stay, the Erasmus parties, personal growth and a good level of education. Most of them found Turkish people very 
friendly. As one Polish Erasmus student stated, 'after my stay I found Turkey more open, developed, friendly and a significant player in the 21st century'. Most of the students differentiated between Istanbul and the rest of Turkey, describing Istanbul as a large, crowded, interesting, exciting city, a melting pot, a meeting point between Europe and Asia.

During their Erasmus experience, students mostly socialised with their friends from the Erasmus programme, who come from different European countries, rather than their Turkish friends. In addition to other social factors, such as sharing a flat, participating in similar courses and Erasmus social activities, the language issue was another challenge for Erasmus students limiting communication with their Turkish friends.

The survey responses indicate that the Erasmus students usually do not focus on academic issues, expecting more to learn about a new culture and improve their language skills. They improved their cultural knowledge during their stay and usually reported stronger self-confidence. Some of them stated that there was a positive change in their perceptions about Turkey after their stay. One of the students from Netherlands commented that 'I found Turkish people and culture much friendlier than I expected.' One of the students from Italy wrote that 'I have to admit, before Erasmus, my perceptions about this country were really different' while a French student stated that 'I am surprised in a really good way'. One of the Erasmus students from Germany commented that 'I was expecting to find Turks in Turkey more different. Here Turkish people are less conservative, more individualistic ... I did not have much contact with German Turks.' Another student from Germany stated that 'I have a better idea about Turkey's EU membership'. A student from Sweden stated that 'there are changes in my perception of Turkey. I did not have a solid image of Turkey before I came but now I feel that I have a very positive experience of Turkish culture'. An Erasmus student from Spain stated that 'my perceptions changed, also my family and visitor friends' perceptions. I found Turkey and Istanbul a more open-minded and friendly society, which is not always the view that the media gives us'.

In addition to the surveys, in-depth interviews were conducted at Bahceşehir University with incoming Erasmus students from various countries, including Germany, France, Spain, Greece and the Czech Republic. Most of the students who chose Turkey reported being interested in Turkey before they came; usually perceiving it as a country that is culturally different from most other European countries. Although only a minority of them had been to Turkey before, most of them were already interested in Turkey, especially Istanbul, before they came. In addition, English is mostly the teaching language at Turkish foundation 
universities, which also influenced their choice. The Erasmus students who were interviewed mostly studied in the department of political science and international relations so they had mostly been already following Turkish politics and Turkey's EU membership bid. A high number of Erasmus students come from Germany, and they emphasized that they wanted to understand and learn about Turkish culture. One of the German Erasmus students stated that 'Germans usually know Turkey from the Turkish immigrants in Germany'. They expected that the Erasmus experience could help them to understand the culture of Turkish immigrants, which might help their communication and integration with them when they returned to Germany. Another German Erasmus student argued that 'German students usually prefer Turkey because they want to know more about Turkish culture and they mostly already have Turkish friends in Germany’.

Most of the interviewees emphasized that they would like to explore a new culture. Most of them stated that they had not known much about Turkey before they had come. Some stated that they knew about former Turkish Prime Minister and current President, R. Tayyip Erdogan, while a few mentioned Turkish singer, Tarkan, Turkish soap operas and Turkey's EU membership bid. During the interviews, which were conducted after the Gezi Park protests, most of the interviewees also mentioned these events. Many of them researched Turkey on the internet after being chosen as Erasmus students to study at a Turkish university. During their stay in Istanbul, most travelled to other cities in Turkey and some visited neighbouring countries. Most of the Erasmus students' family members or close friends visited them during their stay. In addition to the students, the Erasmus programme provides an opportunity for short visits to Turkey, to some family members and friends. In this way, the programme does not only influence the knowledge and perceptions of Erasmus students about the host country but also indirectly influences the perceptions of their friends and family members, although they are limited in number. One French student stated that 'my family was shocked when they learnt that I would come to Turkey. They accepted in the end. They visited me and they felt safe in Istanbul'. A Czech Erasmus student stated that 'a lot of people visited me here. Everybody was surprised and they change their view about Turkey after visiting me here. They were thinking that Turkey is so different'. She added that 'before I came, I was expecting Turkey more traditional too. Some cities are more conservative, but life is more European, especially in Istanbul. Erasmus is different than travelling in that country; while you are travelling you cannot see the life behind. One of the Spanish Erasmus students stated that 'the people in Spain do not know about Turkey. My parents and friends came to visit me. My parents found it similar to Spain'. She added that 'we are the same in Greece, Italy, Turkey and Spain. Spain and Germany do not have any similarity. Istanbul is like Madrid and London. If you travel to the other parts of Turkey, it starts to change’. 
The most frequently used adjectives about Turkey were: different culture, mixed, interesting, multicultural, unique, traditional, friendly. The most frequently used descriptions of Istanbul were open-minded, hospitable, different, multicultural, crowded and friendly people. Some Erasmus students stated that they started to learn Turkish a bit during their stay in Turkey. They mostly differentiated Istanbul and the rest of Turkey. One of the German students stated that 'Istanbul is definitely compatible with European identity.' One of the French students stated that 'I knew more about Istanbul, not so much about Turkey'. One of the German students stated that 'Istanbul is so different than Anatolia'. Another German student, who had a friend from eastern Turkey, visited eastern Turkey too, arguing that 'there is a big gap between the west and eastern parts of Turkey; they are more conservative in the east part'. She added that 'Turkey needs to minimise the gap between western and eastern parts of Turkey. If this gap were decreased, it would be easier to make changes in Turkey and it would be easier to be a member of the EU'. She also stated that 'before my Erasmus experience, I was thinking that Turkey is more conservative and not that open-minded. However, I saw that Turkey is not that different from our cultures. I found Turkey more open-minded than expected'. When she compared Turkish and German cultures, she stated that here it is more emotional, not so rational as in Germany; it would be good if it were so also in German or European culture. Also respect is very important here; not so important in my country'.

Some of the students argued that Turkey combines very controversial ideas within one country, in that religion and traditions are important for some segments of the society. Some of them reported that nationalism is very important in Turkey. In defining Turkish culture and identity, one of the German students stated that in Turkey there are so many different ways of life living together. Some of my Turkish friends are not different from my German friends'. Another German student stated that 'before I came, I thought that Turkey is too different than other European countries. People in my country usually had warned me about Turkey, that they will marry you, you will wear a veil'. One of the students from the Czech Republic stated that 'family is very important in Turkey; religion is one of the most important thing too'. She added that 'society is bound together, which is so nice; that is what we do not have in Europe. We are not like Turkey; we are more individualistic'.

The incoming Erasmus students do not have a common understanding of European identity, although most of them defined European identity on the basis of common values and norms. One of the students from Germany defined it as a lot of different cultures and languages, common history and shared values'. Another German Erasmus student defined it on the basis of 'Western values, democracy, human rights, solidarity and peace'. She defined her identity as 'more European than 
German. I feel already European, now it is stronger'. After their Erasmus experience, some of them stated that they felt a bit more European. One of the French students stated that 'I defined my identity more as a French person; after the Erasmus experience I feel more European'. Most of them have primarily a regional or national identity before a European identity. One of the French students stated that 'when I am in France, I am from my region, when I am in Turkey, I feel more French'. She added that, after my Erasmus experience, 'I feel more French'. One of the German students stated that 'when I am in Germany, I have a strong regional identity'. A Spanish Erasmus student stated that 'I do not have a European identity, I have a Mediterranean identity'. One of the students from the Czech Republic stated that 'I was more negative about working or living abroad; I found it complicated.

However, after my Erasmus experience, I want to discover other cultures and I want to be abroad more.' One of the students from Germany stated that 'I am more open to strangers, more open-minded, losing fear of making new contacts and taking new challenges.'

A few of the students stated that they had already felt European before their Erasmus experience. One of the French Erasmus students stated that 'Erasmus is creating a kind of community. I feel more international'. A few stated that they primarily have a European identity. One Greek student, who mentioned that she is of Turkish origin, stated that, after her Erasmus experience, she feels more Turkish. One Spanish Erasmus student stated that 'I feel at home here', although she added that 'I feel more Spanish here; you miss language and food. I realize the things I like more about Spain'. She emphasized that 'I would like to travel more to have the best identity'. Thus, it seems that the Erasmus experience did not induce a major transformation towards having a European identity; rather, the students usually became more open-minded, more eager to travel and learn about different cultures, and to have more international experience. They were also starting to consider more doing masters in a foreign country or work in a foreign country after their Erasmus experience.

Affected by the recent debt crisis in their countries, the students from Greece and Spain were more sceptical about the EU project, even after their Erasmus experience. One Spanish Erasmus student stated that 'I was feeling a citizen of the world before Erasmus.' She added that 'if I am in Germany, I feel like a second class citizen; if I come to Istanbul, I feel European.' Especially after the economic crisis, some students were thinking about coming back to Turkey to do masters or to work for a certain period. A Spanish Erasmus student stated that in two years, I want to come back to Turkey again. I want to apply for a masters scholarship in Turkey. 
I may work as a guide here.' Some of my former Erasmus students applied for a masters scholarship in Turkey. One former Spanish Erasmus student at Bahcesehir University, after finishing her masters degree in the UK, returned to Turkey, and is currently working for a company in Turkey after working there as an intern.

Regarding Turkey's EU membership, some argued that, if Turkey can meet the criteria and adopt the EU acquis, then it should become an EU member. Some of them criticised the EU's double standards towards Turkey. One of the German Erasmus students stated that 'Turkey is part of Europe. The long accession process of Turkey is not only Turkey's fault, also EU's fault.' Another German student stated that 'nationalism is important for Turkish people, which may be one of the challenges for Turkey while entering the EU'. Some of them mentioned the role of the rise in Islamophobia in Europe as one of the biggest challenges facing Turkey's EU membership bid. In addition, some mentioned the Cyprus issue as another challenge. On the other hand, most emphasised that democratisation and reform processes have to continue. One of the German students stated that 'most of Turkish society supports Western values. But Turkey has a lot of things to do for freedom of press, human rights and minority rights.' Another German Erasmus student stated that 'it is unfair to say Turkey can not be a member because the media is not free. Some countries in the EU, such as Hungary, have similar problems too.' One of the Erasmus students from the Czech Republic stated that 'before I was thinking that Turkey is so different, it would be much harder for Turkey to integrate to the EU. After Erasmus, I saw that they are not so different than us; they are really openminded. Turkish people feel very excluded. If the boundaries are opened, Turkey and the EU can have better relations.' She added that 'after the economic crisis, Turkey does not really need the EU, especially in Istanbul. In the future, maybe it is better for Turkey to stay unique, rather than being part of the EU. I would prefer Turkey to stay aside, because I do not believe in the EU'. One of the German students argued that 'the EU can help Turkey in its transformation process and overcoming regional gaps'. Another German student stated that 'there is so much potential here; if there are some changes, Turkey can be a great member.'

Some of them emphasised Turkey's possible contributions to the EU if becomes a member state, particularly in terms of foreign policy. One of the German students stated that 'after my Erasmus experience, I started to understand TurkeyEU relations better. I am in favour of Turkey's EU membership, but I know that there are problems that are very hard to overcome. One of the biggest challenges for Turkey's accession is its size'. She added that 'if Turkey accedes, it will play a very important role'. Another German Erasmus student stated that 'if Turkey becomes a member of EU, Turkey has to decide which part of the world it should belong to'. As 
a challenge facing Turkey's accession, she argued that 'if Turkey became a member, the EU would have new neighbours like Iran, Iraq, Syria, and I think it would be a big problem. But she added that 'it would be interesting, if Europe were more openminded, if it tried to integrate different cultures ... It would be good for each culture to learn from each other'. However, another German Erasmus student warned that 'if there were a referendum in Austria and France, it would be hard for Turkey to become a member of the EU'. One of the Erasmus students from France stated that 'if there will be a referendum, most of the French people will say no. French people are not ready, not only about Turkey; we are not so much in favour of the EU'. A Spanish Erasmus student stated that 'Turkey should do something in its own way. In the EU, Turkey will be second-class too.' A German Erasmus student claimed that 'if EU gave Turkey a more clear membership perspective, then Turkey would do more reforms. There is no real perspective, so there is no motivation to change'. She added that 'Turkish people are frustrated about the EU. They feel that they have done a lot already, but the EU is not fair to them.' One of the Erasmus students stated that 'the Gezi demonstrations are a good sign, because it shows that they want to have a change'. One of the French Erasmus students stated that 'the EU needs to have close relations with Turkey. Visa free travel is a good idea. Even for economic reasons, it is better for both Turkey and the EU. Thus, during their stay in Turkey as an Erasmus student, particularly those who study in the department of political science and international relations, had a chance to learn more about the challenges and prospects of Turkey's EU membership bid.

\section{Conclusion}

Although Turkey began participating in the Bologna process and the Erasmus programme after EU member states, it has made great progress, with the number of students and academic staff involved increasing a lot since its introduction (Aba 2013, 108). Nevertheless, although numbers of incoming students have been rising in recent years, Turkey is still not a popular destination country for Erasmus students yet.

According to the surveys that were conducted at the beginning of the semester, Erasmus students' main reasons for choosing Turkey were discovering Turkish culture and Istanbul, which they found different and interesting. One of the students from Germany wrote that 'I chose Istanbul more than Turkey', and added that 'Istanbul is rich in terms of culture, history and life.' In addition, they usually reported coming to meet people from different countries and to make friends from different European countries, to improve their English, to learn Turkish, and to visit new places. Nearly all of them had not known much about Turkey before they 
came, and most had not visited before. Most of them did not have a prejudice about Turkey before. When asked what they had known before they came, most mentioned knowing where Turkey is and parts of its history. Some heard recommendations about Turkey from friends who had participated in the Erasmus programme. The students were usually open-minded and eager to learn different cultures, having already been interested in Turkey, Turkish culture or different cultures before they had come. Most of them wanted to discover Turkish culture, which they found interesting and different from other European countries. Some of them expected to improve their level of English. They had heard more about Istanbul than the rest of Turkey. German students, in particular, emphasized that they would like to learn more about Turkish culture in order to understand Turkish immigrants in Germany better. Most of the German students chose Turkey to understand and learn more about Turkish culture due to the presence of the Turkish community in their country.

By the end of their stay, nearly all of them had enjoyed being in Istanbul. Nearly all of them found Turkish people hospitable and friendly. Thus, the Erasmus experience has a strong effect on the perceptions of the incoming students about Turkey. However, it has to be mentioned that most of them did not have a prejudice about Turkey and they would like to discover and understand a new culture. Although they had not known much about Turkey before arriving, they were mostly interested in learning different cultures. Although they mostly did not become more European after their Erasmus experience, they became more open-minded, and more interested in studying and working in different countries. Thus, the Erasmus programme has some ability to help overcome prejudices and stereotypes about Turkey, although it is limited. They mostly differentiated between Istanbul and the rest of Turkey, although some did not visit other areas. They found Istanbul exciting and similar to other European cities and European culture.

The Erasmus programme not only influences those who participate in the programme but also those who do not participate (Maiworm 2001). The family, relatives and friends of participating students sometimes visited them during their Erasmus stay. In addition, when Erasmus students go back to their countries, they share their experiences with their family and friends. This study found that most of the students' parents, even those who had prejudices about Turkey, visited their children and mostly liked Turkey, particularly Istanbul, which caused them to change their perceptions.

The Erasmus students tended to become more aware of the real challenges and contributions of Turkey's accession to the EU for both sides, especially the students 
of political science and international relations and European Union studies. Most of them argued that Turkey can become a member if it continues the reform process.

There are some limitations in this study. Firstly, the research was conducted only at one university in Istanbul. Open-ended questionnaire surveys were conducted with different students at the beginning and end of the semesters, while in-depth interviews were conducted only at the end of the semester after their Erasmus experience. For future studies, it would be better to hold in-depth interviews both at the beginning and end of the semester with the same students because they might already have positive perceptions towards Turkey having chosen this country for their Erasmus programme. This research needs to be extended to different universities in different cities to further investigate the influence of the Erasmus programme on the perceptions of incoming students about Turkey.

Further research is needed concerning the prejudices of outgoing Turkish Erasmus students, and how their Erasmus experience influences their perceptions about the EU, European culture and the Erasmus programme, how their Erasmus experience changes their views of Turkey's EU membership bid, as well as their sense of European identity.

\section{References}

Aba, D. 2013. 'Internationalization of Higher Education and Student Mobility in Europe and the Case of Turkey', Cukurova University Faculty of Education Journal, 42, Issue 2, pp.99-110.

Aydin, S. 2012. 'I am not the same after my Erasmus': A Qualitative Research', The Qualitative Report, 17, No. 55, pp. 1-23.

Brock, C. and Tulasiewicz, W. 1999. Education in Single Europe (New York: Routledge Pub.).

Council of the European Communities. 1987. Council decision of 15 June 1987 adopting the ERASMUS. Official Journal of the European Communities, pp. 20-24.

Demirkol, A. Y. 2013. 'The Role of Educational Mobility Programs in Cultural Integration: A Study on the Attitudes of Erasmus Students in Turkey toward the Accession of Turkey to European Union', Anthropologist, 16, No. 3, pp. 653-661.

Erasmus: Facts, Figures and Trends. 2014. The EU Support for Student and Staff Exchanges and University Cooperation in 2012-2013 (Luxembourg, Publications Office of the EU).

Fligstein, N. 2009. 'Who are the Europeans and How does this matter for Politics?' in: J. Checkel and P. J. Katzenstein (Eds), European Identity (Cambridge, Cambridge University Press).

Keles, Yener. 2013. 'What Intercultural Communication Barriers do Exchange Students of Erasmus Program have during their Stay in Turkey, Mugla?', Procedia-Social and Behavioral Sciences, 


\section{S. Oner}

70, pp. 1513-1524.

King, R. and Ruiz-Gelices, E. 2003. 'International Student Migration and the European Year Abroad: Effects on European Identity and Subsequent Migration Behaviour', International Journal of Population Geography, 9, No. 3, pp. 229-252.

Krzaklewska E. and Krupnik, S. 2008. 'The Role of the Erasmus Programme in Enhancing Intercultural Dialogue: Presentation of the Results from the Erasmus Student Network Survey 2007', Proceedings of the 4th International Barcelona Conference on Higher Education, Higher Education for Intercultural Dialogue and Multiculturalism, 6, Barcelona: GUNI, Available at: www.guni-rmies.net

Maiworm, F. M. 2001. 'Erasmus: Continuity and Change in the 1990s', European Journal of Education, 36, No. 4, pp. 459-472.

Mitchell, K. 2012. 'Student Mobility and European Identity: Erasmus Study as a Civic Experience?', Journal of Contemporary European Research, 8, No. 4, pp. 490-518.

Mutlu, S. 2011. 'Development of European Consciousness in Erasmus Students', Journal of Education Culture and Society, No. 2, pp. 87-102.

Mutlu, S., Alacahan, O. and Erdil, M. 2010. 'Comparison of the Personal and Cultural Change Taking Place between EU Erasmus Students and Turkish Erasmus Students (within the sample of Adam Mickiewicz University in the city of Poznan, Poland)', Eurasian Journal of Anthropology, 1, No. 1, pp. 33-43.

Oborune, K. 2013. 'Becoming More European after Erasmus? The Impact of the Erasmus Programme on Political and Cultural Identity', Epiphany: Journal of Transdisciplinary Studies, 6, No. 1, pp. 182-202.

Reilly, J. 1993. 'The Erasmus Experience', in Cunningham, L. (ed.), Student Skills for the New Europe, Ledds: HEC.

Sigalas, E. 2010. 'Cross-border Mobility and European Identity', European Union Politics, 11, No. 2, pp. 241-265.

Sigalas, E. 2009. 'Does ERASMUS Student Mobility Promote a European Identity?', ConWEB: Webpapers on Constitutionalism \& Governance beyond the State, No 2, pp.1-23.

Sigalas, E. 2006. 'Remaining Proud of Their National Identity, yet Uniting ever more Closely? The Erasmus Students as the Role Model European Citizens', Available at: http://web.uvic.ca/ ecsac/biennial2006/pdf/Emmanuel-Sigalas.pdf

Studying in Turkey for Erasmus. 2010. Turkish National Agency, The Centre for UE Education and Youth Programmes (Ankara, Impress Pub.).

Van Mol, C. 2011. 'The Influence of European Student Mobility on European Identity and Subsequent Migration Behaviour' in: F. DERVIN (Ed), Analysing the Consequences of Academic Mobility and Migration (Newcastle: Cambridge Scholars Publishing). 
Van Mol, C. 2009. 'The Influence of European Student Mobility on European Identity and Subsequent Migration Intentions', International Bilingual Conference 'Academic Mobility: New Researches and Perspectives', Talin University, Available at: file://C:/Users/ VAIO/Downloads/00234438.pdf

Wilson, I. 2011. "What Should We Expect of 'Erasmus Generations'?”, Journal of Common Market Studies, 49, No. 5, pp. 1113-1140. 